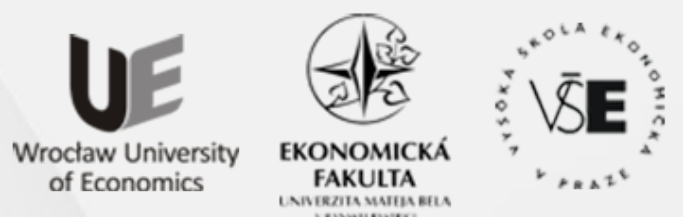

Conference Proceedings

Full TeXT PAPERS

edited by

Zofia Rusnak and Beata Zmyślona

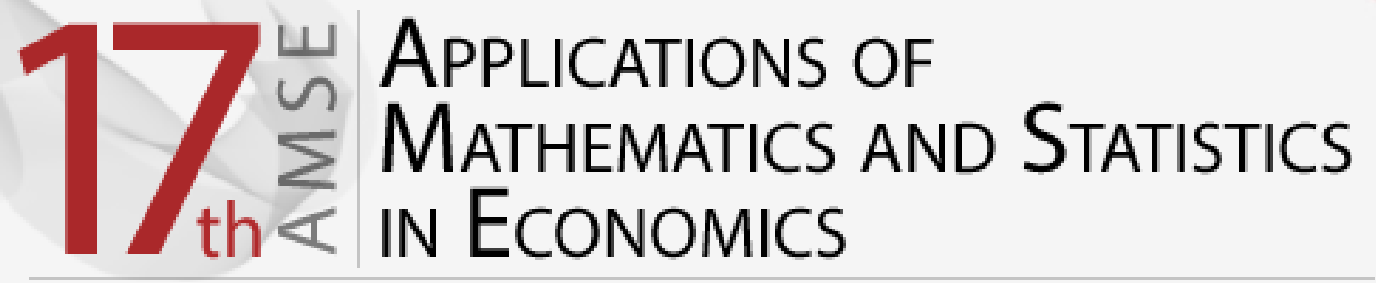

International Scientific Conference | Poland • 27-31 August 2014 
Scientific Committee

Richard Hindls, Stanislava Hronová, Rudolf Zimka, Walenty Ostasiewicz, Emília Zimková, Zofia Rusnak, Martin Bod'a

Organizing Committee

Beata Zmyślona, Cyprian Kozyra, Grzegorz Rogoziński, Kristýna Vltavská

\section{Reviewers}

Milan Bašta, Diana Bílková, Martin Bod'a, Joanna Dębicka, Tomáš Fiala, Jakub Fischer, Stanisław Heilpern, Karel Helman, Lenka Hudrlíková, Miroslav Hužvár, Nikola Kaspř́ková, Alena Kaščáková, Kamil Kladívko, Jindřich Klůfa, Pavol Král', Katarzyna Kuziak, Jana Langhamrová, Ivana Malá, Tomáš Marcinko, Luboš Marek, Miloš Maryška, Petr Mazouch, Zofia Mielecka-Kubień, Witold Miszczak, Petr Musil, Gabriela Nedelová, Walenty Ostasiewicz, Iva Pecáková, Viera Roháčová, Zofia Rusnak, Mária Stachová, Jana Špirková, Šárka Šustová, Jana Tepperová, Vladimír Úradníček, Kristýna Vltavská, Michal Vrabec, Dariusz Wawrzyniak, Henryk Zawadzki, Jaroslav Zbranek, Tomáš Zeithamer, Martin Zelený, Jan Zeman, Rudolf Zimka, Emília Zimková, Pavel Zimmermann, David Žižka

Layout

Martin Bod'a, Beata Zmyślona, Grzegorz Rogoziński

Front page design

Grzegorz Rogoziński

CD cover design

Beata Dębska

Articles published in the form submitted by the authors

All rights reserved. No part of this book may be reproduced in any form or in any means without the prior permission in writing of the Publisher

(C) Copyright by Wrocław University of Economics Wrocław 2014

ISBN 978-83-7695-421-9

Wydawnictwo Uniwersytetu Ekonomicznego we Wrocławiu

53-345 Wrocław, ul. Komandorska 118/120 www.ue.wroc.pl

Sprzedaż książek tel./fax 71 36-80-602

e-mail: econbook@ue.wroc.pl www.ksiegarnia.ue.wroc.pl 


\section{Contents}

Foreword

Diana Bílková: TL-Moments: Analogy of Classical L-Moments

Dagmar Blatná: Application of Robust Regression in the Analysis of Internet Access in European Countries

Martin Bod’a, Mária Kanderová: Rebalancing Issues in Tracking Error Variance Minimization

Martin Bod'a, Viera Roháčová: Application of Six Sigma Ideas to Timing Decisions at Financial Markets

Anton Dekrét, Rudolf Zimka: On the Price Hartwick's Task and Its Inverse in a Dynamic Model of an Economy with Exhaustible Resources

Joanna Dębicka, Agnieszka Marciniuk: Comparison of Reverse Annuity Contract and Reverse Mortgage on the Polish Market.

Petra Dotlačilová, Jitka Langhamrová: The Influence of Mortality Models for the Expected Future Life-time of Older People

Marek Ďurica, Lucia Švábová: Delta and Gamma for Chooser Options.

Vlastimil Farkašovský: New Concept of Pension Funds Performance Evaluation

Albert Gardon: The Normality of Weekly Relative Changes of the Freight Rate in Container Shipping.

Mária Grausová, Miroslav Hužvár, Jana Štrangfeldová: Healthcare Systems Efficiency in the Visegrád Group.

Stanisław Heilpern: Multiple Life Insurance - Pension Calculation

Alena Kaščáková, Gabriela Nedelová: Changes in Slovak Households' Economy

Igor Kollár, Pavol Král', Peter Laco: Methodology for Assessing Website Improvement in Corporate Environment.

Maciej Kostrzewski: Some Method of Detecting the Jump Clustering Phenomenon in Financial Time Series.

Cyprian Kozyra, Beata Zmyślona, Katarzyna Madziarska: Complementary Objective and Subjective Measures of Hospital Services Quality...

Pavol Král', Mária Stachová, Lukáš Sobíšek: Utilization of Repeatedly Measured Financial Ratios in Corporate Financial Distress Prediction in Slovakia

Ivana Malá: The Use of Finite Mixture Model for Describing Differences in Unemployment Duration

Lukáš Malec: Studying Economics and Tourism Industry Relations by Smooth Partial Least Squares Method Depending on Parameter. 
Tomáš Marcinko: Consequences of Assumption Violations Regarding Classical Location Tests.

Edyta Mazurek: The Income Tax Progression Depending on Social Insurance Contribution in Poland.

Petr Musil, Jana Kramulová, Jan Zeman: Regional Consumption Expenditures: An Important Starting Point for Regional Input-output Tables.

Katarzyna Ostasiewicz, Walenty Ostasiewicz: Good Life: From Political to Human Economy

Anna Sączewska-Piotrowska: Analysis of Poverty Transitions in Poland Using Multilevel Discrete-Time Event History Models

Martina Šimková, Petra Švarcová: Disadvantaged University Students in the Czech Republic.

Michal Široký: The Use of Short-term Business Statistics for Quarterly GDP Flash Estimates in the Czech Republic

Zdeněk Šulc, Hana Řezanková: Evaluation of Recent Similarity Measures for Categorical Data.

Lucia Švábová, Marek Ďurica: The Relationship Between the Finite Difference Method and Trinomial Trees

Kristýna Vltavská, Jaroslav Sixta: The Estimation of Final Consumption Expenditures

Lenka Vraná: Business Cycle Analysis: Tracking Turning Points

Janusz Wywiał: On Bayesian Testing in Auditing

Emília Zimková: Window Analysis of Supper-efficiency Change: Case of the Slovak Banking System ....

Beata Zmyślona: Statistical Modelling of the Impact of Diabetes on the Risk of Hospitalization 


\title{
APPLICATION OF SIX SIGMA IDEAS TO TIMING DECISIONS AT FINANCIAL MARKETS
}

\author{
MARTIN BOĎA \\ Matej Bel University in Banská Bystrica, Faculty of Economics, Department of Quantitative Methods \\ and Information Systems, Tajovského 10, 97590 Banská Bystrica \\ email: martin.boda@umb.sk \\ VIERA ROHÁČOVÁ \\ Matej Bel University in Banská Bystrica, Faculty of Economics, Department of Quantitative Methods \\ and Information Systems, Tajovského 10, 97590 Banská Bystrica \\ email: viera.rohacova@umb.sk
}

\begin{abstract}
As a gauge of quality efficiency, a measure of excellence and a quality improvement system based on statistical probability measurement and process capability technique, Six Sigma is very popular in the area of corporate management of manufacturing firms and business enterprises. The idea of this paper is to apply this managerial methodology to the area of financial management and to develop a framework for its application in timing of financial decisions concerning rebalancing of an existent portfolio of financial assets. The anticipated contribution of the paper, except its original idea, lies in the proposal of a new methodology for investors at financial markets and in verification of this proposal in the light of a small case study. The application of this methodology requires a procedure for setting the sigma level for a given portfolio, and this task is fully addressed in the paper.
\end{abstract}

Key words: Six Sigma, portfolio of assets, sigma level, rebalancing strategy.

DOI: $10.15611 /$ amse.2014.17.04

\section{Introduction}

All processes in nature are unfortunately far from perfect. Variations around the desired output value of a process or a product are always present and they can have different causes. The doctrine Six Sigma was developed by Motorola in 1986 and represents a set of techniques and tools for process improvement. Six Sigma seeks to improve the quality of process outputs by identifying and removing causes of defects and minimizing variability in manufacturing and business processes. In a narrow statistical sense, Six Sigma is a quality objective that identifies variability of a process in terms of product specifications so that product quality and reliability meet and exceed today's demanding customer requirements (Stamatis, 2004, p. 2). For this purpose it uses a set of quality management methods, including statistical methods.

The Six Sigma methodology is widely used in the area of corporate management of manufacturing firms and business enterprises, it certainly possesses a great potential and offers a chance of application in other fields. This is fully understood by the authors who are entertaining the idea of its application in the area of financial investing, and are presenting this idea in its rough form in the paper. 
The philosophical standpoint adopted in the paper treats financial portfolios as processes that can be regulated and thus fall within the scope of Six Sigma. A financial portfolio, no matter whether held with constant weights or rebalanced, can be thought of as a process with certain performance characteristics (such as returns, mean return, volatility, even mean-returnto-volatility ratio). These performance characteristics may then be compared with performance characteristics of a suitably chosen benchmark, and this comparison is the basis for judging the quality of this process. The idea of the paper is to set the sigma level for an existent portfolio of assets by comparing its behaviour with the behaviour of a benchmark, and then to use it as a standard for timing when and whether to rebalance. This is due to the fact that asset prices change over time and so does portfolio values. If with these changes the current sigma level has devolved, this should be treated as a stimulus for intervention and for portfolio rebalancing.

The goal of the paper is hence to develop a rough sketch of a rebalancing strategy grounded in the Six Sigma methodology using the sigma level indicator. Aside from the theoretical formulation of the new approach to rebalancing, an empirical demonstration of its application is provided under the task minimum-variance portfolio selection, which is a Markowitzian method in active asset management. Note that a certain portion of emphasis is given upon the phrase "a rough sketch" as this concept will need some other refinement, improvement and testing before putting fully into practise.

The paper is organized into five sections. This first section is introductory and the final section concluding. The core sections of the paper successively present the basics of Six Sigma (the second section), their adaptation to portfolio construction and the portfolio selection task (the third section) and eventually the design and results of the empirical exercise demonstrating the issues (the fourth section).

\section{Six Sigma methodology and its use in improvement of processes}

The crucial aim of the Six Sigma methodology is to eliminate defects and waste by measuring and reducing variations. The ultimate goal is to satisfy the customer who defines quality. He expects high performance, reliability, competitive prices and quality service; and everything that is out of his expectations is considered as defect. It is necessary to know or find out the voice of the customer in order to capture the customer's expectations, preferences and aversions. Based on knowledge of customer requirements, Six Sigma identifies priority areas and processes in which the company could achieve significant improvements. Subsequently, Six Sigma applies tools to uncover the causes of defects and shortcomings and tools to remove them.

Over the last few years, Six Sigma has gained a wide popularity and many companies have applied this methodology in different fields, with considerable results in money and time saving. The most known and interesting experiences, which have been taken as a reference for extraordinary results, are those developed in Motorola, Bank of America, General Electric, Toyota and many other companies operating all over the world.

There are many perspectives or definitions of Six Sigma. Conventionally it can be understood as: (1) a way of measuring quality, which allows comparing different processes; (2) a project-oriented methodology for solving problems using statistical tools; (3) a quality improvement system aimed at reducing defects or (4) a philosophy and management strategy focused on customer satisfaction and decision-making based on verified data. 
Another point of view says that the Six Sigma method has two major perspectives (Kwak and Anbari, 2006). From the business viewpoint, Six Sigma is defined as a business strategy that employs a well-structured continuous improvement methodology to reduce process variability and drive out waste within business processes (Bañuelas et al., 2005, p. 553). From the statistical viewpoint adopted in this paper, Six Sigma is discussed in a statistical, probabilistic and quantitative manner, in which sigma is a term used to represent variation about the process target value or expected value.

The name Six Sigma indicates the level of quality that should be achieved by a process or by a product. The conceptual underfooting of the methodology is that the business process could be characterized by certain variables (i.e. parameters or indicators) of its quality. Usually, values of many process quality indicators are centred symmetrically about the mean value and the results are the more unlikely, the more they distance themselves from their mean value. The statistical basis of the Six Sigma concept is the assumption that stochastic processes follow the Gaussian paradigm $\mathrm{N}\left(\mu, \sigma^{2}\right)$, in which $\sigma$ is standard deviation of the process quality indicator and is used to express the degree of variability of the process around the mean value $\mu$.

Voice of the customer is represented by the lower specification limit (LSL) and the upper specification limit (USL) for the selected process quality indicator. Everything that is outside this tolerance interval is considered to be a defect. The sigma quality level indicates how often defects are likely to occur. This quality level is also expressed as Defects per Million of Opportunities $(D P M O)$ defining the probability that the process output does not satisfy the required limits. The DPMO indicator obeys the following formula:

$$
D P M O=\frac{\text { number of defects }}{\text { number of units } \times \text { number of opportunities per unit }} \times 1,000,000 .
$$

The key statistical idea of Six Sigma is that in a million opportunities for defect no more than 3.4 actual defects should occur, i.e. Six Sigma's implicit goal is to improve all processes to $3.4 D P M O$ level. If one can suppose that the process is Gaussian, one may expect that approximately $99.9999998 \%$ of the values are located in the interval $\mu \pm 6 \sigma$. The probability of defect in this case is at the level $0.0000002 \%$ and DPMO is on the level of 0.002 defects per million opportunities. However, as was said, Six Sigma's implicit goal is to improve all processes to 3.4 DPMO level. Experience has shown that processes usually do not perform as well in the long horizon as they do in the short term. As a result, the number of standard deviations that will fit between LSL and USL may well drop over time, compared to the initial short-term study (due to fatigue of material, machine wear, changing external conditions). This real-life increase in process variation over time could be taken into account by introducing an empirically-based 1.5 sigma shift into the calculation.

If we consider this 1.5 sigma shift of mean in time, we can express the empirical probability of defects by the formula

$$
\Phi(-k-1.5)+(1-\Phi(k-1.5))=\frac{D P M O}{1,000,000},
$$

where $k$ denotes the unknown sigma level of the process. It is clear that for the interval $\mu \pm$ $6 \sigma, k$ is equal to 6, i.e. the Six Sigma level is achieved. Processes with higher sigma level are those, in which there is a lower probability of defect causing dissatisfaction or failure of the specified requirements. 
Table 1 shows probability to fall inside the interval $(\mu \pm k \sigma)$, probability of defect and $D P M O$ for various choices of $k$, imposing normality with and without a shift of 1.5 multiple of standard deviation $\sigma$. The DPMO 3.4 is associated with $k=6$ and with a $1.5 \sigma$ shift in the process mean (for more details see e.g. Montgomery, 2001, Linderman et al., 2003).

Table 1. Properties Six Sigma processes for various sigma-levels and sigma ranges

\begin{tabular}{|c|c|c|c|c|c|c|}
\hline \multirow{2}{*}{$\begin{array}{l}\text { Sigma range } \\
\text { specification }\end{array}$} & \multicolumn{3}{|c|}{ Without a $1.5 \cdot \sigma$ shift } & \multicolumn{3}{|c|}{ With a $1.5 \cdot \sigma$ shift } \\
\hline & $\begin{array}{c}\text { Probability } \\
\text { of falling inside }\end{array}$ & $\begin{array}{c}\text { Probability } \\
\text { of defect }\end{array}$ & DPMO & $\begin{array}{c}\text { Probability } \\
\text { of falling inside }\end{array}$ & $\begin{array}{c}\text { Probability } \\
\text { of defect }\end{array}$ & DPMO \\
\hline$\mu \pm \sigma$ & $68.27 \%$ & $31.73 \%$ & $317,310.51$ & $30.23 \%$ & $69.77 \%$ & $697,672.13$ \\
\hline$\mu \pm 2 \sigma$ & $95.45 \%$ & $4.55 \%$ & $45,500.26$ & $69.12 \%$ & $30.88 \%$ & $308,770.17$ \\
\hline$\mu \pm 3 \sigma$ & $99.73 \%$ & $0.27 \%$ & $2,699.80$ & $93.32 \%$ & $6.68 \%$ & $66,810.60$ \\
\hline$\mu \pm 4 \sigma$ & $99.99 \%$ & $0.01 \%$ & 63.34 & $99.38 \%$ & $0.62 \%$ & $6,209.68$ \\
\hline$\mu \pm 5 \sigma$ & $99.9999427 \%$ & $0.0000573 \%$ & 0.57 & $99.98 \%$ & $0.02 \%$ & 232.63 \\
\hline$\mu \pm 6 \sigma$ & $99.9999998 \%$ & $0.0000002 \%$ & 0.002 & $99.99966 \%$ & $0.00034 \%$ & 3.40 \\
\hline
\end{tabular}

Source: The authors and Breyfogle (2003, p. 14).

The concept of Six Sigma is in more depth described by e.g. Schroeder et al. (2008) or Zu et al. (2008).

\section{Setting sigma level of a portfolio and minimum-variance portfolio selection task}

In applying the Six Sigma methodology to tasks of financial investment, it is built upon the sigma level indicator as an objective criterion of investment process quality. The rebalancing strategy rests in calculating sigma levels for the portfolio held over time and in monitoring their development. If the sigma level of the portfolio decreases, this should be taken as a reason for intervention and changing its composition. Another essential ingredient of the rebalancing strategy is the necessity of a benchmark since sigma levels are determined by comparing returns of the portfolio with returns of the benchmark.

In explaining the methodology, assume that the existing portfolio composed of $n$ assets has a history of historical returns $r_{1}, \ldots, r_{T}$ and that the history of benchmark returns for this period is $r_{\mathrm{B}, 1}, \ldots, r_{\mathrm{B}, T}$. A case when the portfolio return is lower than the benchmark return is treated as an undesirable incident, or a defect. There are $T$ time instances when such a comparison is effected (and a defect can be observed), and a total of $n+1$ opportunities for defect per time instance. The reasoning for the latter statement is that there are $n$ internal sources for an occurrence of a defect because they are represented by $n$ returns on the assets forming the portfolio and are more or less under control of the investor. It is the investor who selects assets and their participation in the portfolio at his own discretion (possibly using some optimization task such as implemented here in the paper). In addition, there is one external source for an occurrence of a defect, which is carried by the benchmark and embodied in its return. Therefore, the DPMO indicator may be calculated using the expression

$$
D P M O=\frac{\#\left\{r_{i}<r_{\mathrm{B}, i}\right\}}{T \times(n+1)} \times 1,000,000 .
$$

Using relationship (2), the DPMO is converted to the sigma level $k$ of the portfolio.

In some future time (such as next day, next week, next month etc.) the situation on the market will change and a new history of historical returns will be available. This new data may be then used to estimate the new value of DPMO and to determine the new value of sigma level. If the new sigma level indicates a (substantial) decrease, this is suggestive that 
the quality of portfolio deteriorated over time and that a revision of its weights should be contemplated. The current portfolio weights should be reconsidered by employing a suitable portfolio selection approach. Never the less, it may happen that an update of weights may not be advantageous. If under the new weights the sigma level is worse than the sigma level at the previous of weights, considerations about updating the portfolio composition should be discarded and it is advisable to remain with the previous portfolio without its update. This procedure is further explained in the next section when the design of the empirical exercise is described.

In portfolio construction and determination of weights, the Markowitzian approach of minimum-variance portfolio selection is employed in the paper for demonstrative purposes, and its methodology is communicated and clarified in this paragraph. Suppose that $n$ risky asset returns are represented by a random vector $\mathbf{R}=\left(R_{1}, \ldots, R_{n}\right)^{\prime}$ that has an expectation $\boldsymbol{\mu}=\left(\mu_{1}, \ldots, \mu_{n}\right)^{\prime}$ and an $n \times n$ covariance matrix $\boldsymbol{\Sigma}=\left(\sum_{i j}\right)_{n \times n}$ (the diagonal elements $\Sigma_{i i}$ are variances $\sigma_{i}{ }^{2}$ of individual returns and non-diagonal elements are respective covariances). Assume for now that both the expectation $\mu$ and the covariance matrix $\Sigma$ are known. Any portfolio $\Pi$ with a set of $n$ weights $\omega=\left(\omega_{1}, \ldots, \omega_{n}\right)^{\prime}$ that decide allocation of available financial funds across individual risky assets has expected return $\omega^{\prime} \mu$, variance $\omega^{\prime} \Sigma \omega$ and standard deviation (volatility) $\sqrt{ } \omega^{\prime} \Sigma \omega$. All attainable portfolios are represented by coordinates $\left[\omega^{\prime} \mu, \sqrt{ } \omega^{\prime} \Sigma \omega\right]$ in the Cartesian plane, the first coordinate is given by the expected return of a given portfolio whilst the second represents its standard deviation (volatility). The two-dimensional (expected return $\times$ standard deviation) space of portfolios generated (spanned) by risky assets is called frequently the mean-variance space and it can be shown that it is in the form of a hyperbole which intersects the Cartesian plane and determines the set of all attainable portfolios (c. f. Prigent, 2007, pp. 73-74). The upper arc of this hyperbole is made up of those portfolios that attain the highest expected return possible at the given level of risk expressed by standard deviation / volatility. These portfolios are addressed as efficient in the sense of Markowitz (also known as Markowitz-efficient or mean-variance efficient) portfolios and form the efficient frontier. The portfolio with the minimum standard deviation (volatility) is called the minimum variance portfolio (or the mean variance portfolio). Denote a vector of $n$ ones by 1 and introduce the following quantities

$$
\mathrm{A}=\mathbf{1}^{\prime} \Sigma^{-1} \mu, \mathrm{B}=\boldsymbol{\mu}^{\prime} \Sigma^{-1} \mu, \mathrm{C}=\mathbf{1}^{\prime} \Sigma^{-1} \mathbf{1} \text { and } \mathrm{D}=\mathrm{BC}-\mathrm{A}^{2} .
$$

When shortselling is allowed and there are no constraints except the requirement that the weights must sum to one, the coordinates of the minimum variance portfolio in the meanvariance space are then given by $[1 / \sqrt{ } \mathrm{C}, \mathrm{A} / \mathrm{C}]$, and the vector of weights $\omega^{\#}$ of its allocation across the $\mathrm{n}$ risk assets is given by

$$
\left.\omega^{\#}=\mathrm{D}^{-1}\left(\mathrm{~B} \Sigma^{-1} \mathbf{1}-\mathrm{A} \Sigma^{-1} \boldsymbol{\mu}\right)-\mathrm{A}(\mathrm{CD})^{-1}\left(\mathrm{~A} \Sigma^{-1} \mathbf{1}-\mathrm{C} \Sigma^{-1} \mu\right)\right)
$$

(see Prigent, 2007, pp. 72-73).

Figure 1 displays a mean-variance space generated by 15 risky assets (indicated by dot symbols). The two arcs of the hyperbole demark the set of all attainable portfolios composed of the 15 risky assets under consideration and the upper bold-line arc distinguishes the efficient frontier. The triangle symbol highlights the minimum variance portfolio.

Naturally, in practical applications it is necessary to estimate the expectation vector $\mu$ and the covariance matrix $\Sigma$ and these estimates are formed and computed out of time series 
of historical observations on $n$ asset returns. Ordinarily, the expectation vector $\mu$ is estimated by simple or (exponentially) weighted averaging of individual historical asset returns and the covariance matrix $\Sigma$ by an unbiased estimator or by an (exponentially) weighted estimator. Since these estimators are well known and used by default, their description is omitted here. For simplicity, they are used in the paper as well.

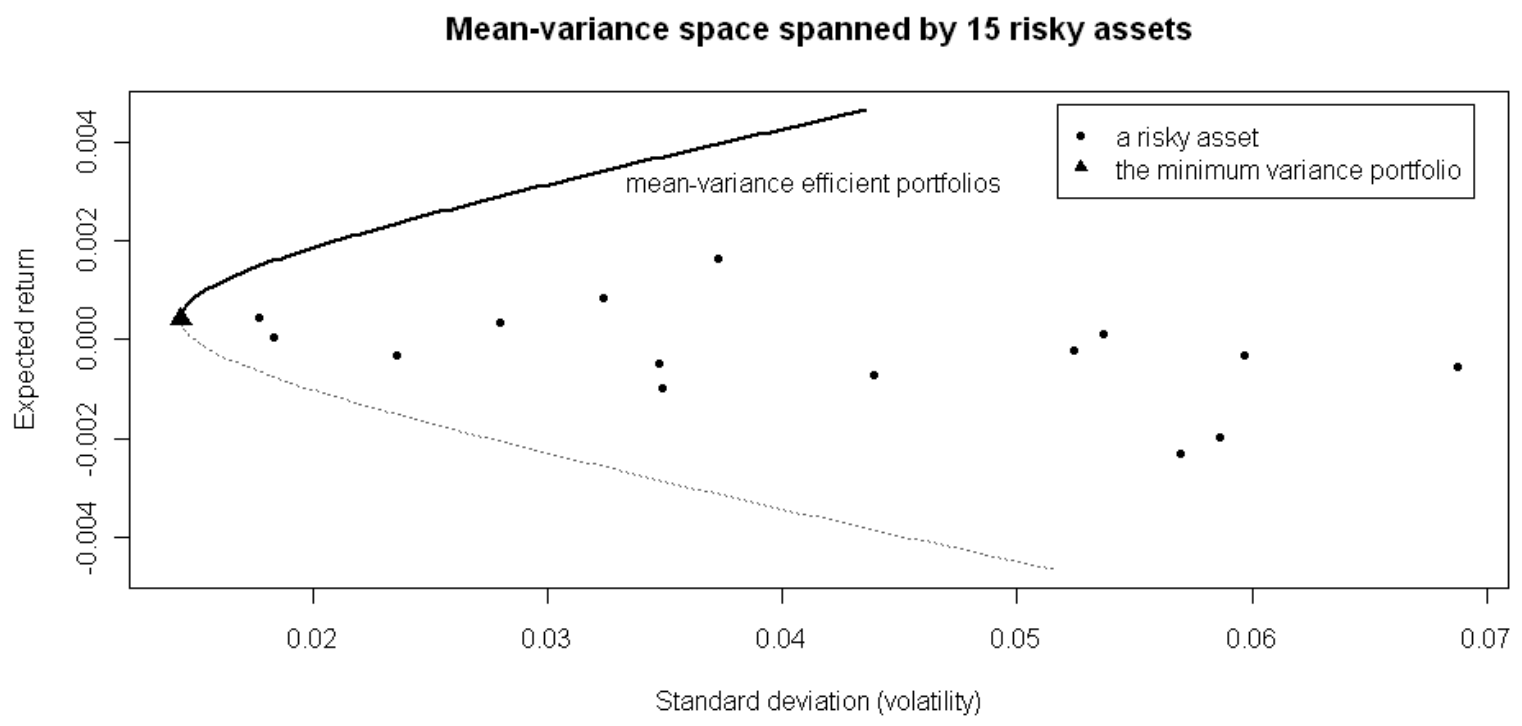

Figure 1 An illustration of the mean-variance space Source: The authors.

\section{Empirical exercise, its practical aspects and results}

The empirical exercise utilized the data observed on a monthly frequency. The in-sampleperiod spanned 5 years from Jan 2006 to Jan 2011 and included 60 effective observations of monthly returns, and the out-of-sample period represented another 3 years from Jan 2011 to Feb 2014 counting 36 monthly instances in which the tracking portfolio might be rebalanced. A stratified sampling of 40 shares represented in the S\&P 500 Index (as of March 2014) was made respecting the classification of shares according to the Global Industry Classification Standard (GICS) taxonomy. It clearly follows from this manner of selection that the S\&P 500 Index acts as a benchmark to which the behaviour and performance of the sigma level rebalancing strategies was compared.

The sampling was undertaken under the design of randomness respecting one additional criterion for sampling, which was the requirement that shares have a sufficiently long history dating back to 2006. In consequence of this criterion draws on three single shares had to be repeated to make sure that they are compliant with this requirement. The list of shares participating in the exercise is provided in Table 2 with their categorization indicated. The total selection of 40 shares was divided heuristically with respect to their alphabetic order into two sub-samples counting 20 shares each. They are indicated in Table 2 as Sample 1 and Sample 2 and called in this manner consistently throughout the further text. The full sample of 40 shares is then addressed as the full sample or as Sample $1 \& 2$. Whilst the full sample is characterized by a random stratified design, both Sample 1 and Sample 2 are clearly chosen arbitrary and cannot be attributed as random. 
Table 2.The shares participating in the empirical exercise

\begin{tabular}{|c|c|c|c|}
\hline \multicolumn{2}{|c|}{ Sample 1} & \multicolumn{2}{|c|}{ Sample 2} \\
\hline Company name & GICS sector & Company name & GICS sector \\
\hline Amazon.com Inc & Consumer Discretionary & Wells Fargo & Financials \\
\hline CBS Corp. & Consumer Discretionary & Allergan Inc & Health Care \\
\hline Ford Motor & Consumer Discretionary & Becton Dickinson & Health Care \\
\hline Goodyear Tire \& Rubber & Consumer Discretionary & Boston Scientific & Health Care \\
\hline Mohawk Industries & Consumer Discretionary & Medtronic Inc. & Health Care \\
\hline TJX Companies Inc. & Consumer Discretionary & 3M Company & Industrials \\
\hline Whirlpool Corp. & Consumer Discretionary & Fastenal Co & Industrials \\
\hline Avon Products & Consumer Staples & Flowserve Corporation & Industrials \\
\hline Mondelez International & Consumer Staples & Fluor Corp. & Industrials \\
\hline PepsiCo Inc. & Consumer Staples & Roper Industries & Industrials \\
\hline Chevron Corp. & Energy & Broadcom Corporation & Information Technology \\
\hline CONSOL Energy Inc. & Energy & Jabil Circuit & Information Technology \\
\hline Exxon Mobil Corp. & Energy & Microchip Technology & Information Technology \\
\hline Noble Corp & Energy & Salesforce.com & Information Technology \\
\hline Fifth Third Bancorp & Financials & Yahoo Inc. & Information Technology \\
\hline Huntington Bancshares & Financials & The Mosaic Company & Materials \\
\hline Northern Trust Corp. & Financials & Owens-Illinois Inc & Materials \\
\hline Plum Creek Timber Co. & Financials & AT\&T Inc & Telecommunications Services \\
\hline Progressive Corp. & Financials & Exelon Corp. & Utilities \\
\hline SunTrust Banks & Financials & Pinnacle West Capital & Utilities \\
\hline
\end{tabular}

Source: The authors.

A total of four investment strategies were considered in allocating the amount of U.S. \$ 100,000 at the end of the in-sample period as of 3 Jan 2011. In order that performance evaluation of the three sigma level rebalancing strategies is more complex, an investment into the S\&P 500 Index as of 3 Jan 2011 was made and this investment was not revised over the out-of-sample period. This portfolio serves as an objective criterion for portfolio behaviour and performance. In addition to this, three sigma level rebalancing portfolios were created for Sample 1 of 20 shares, Sample 2 of another 20 shares and for the full sample of 40 shares, in which the following procedure was adhered to:

First, on the basis of in-sample monthly returns, the vector of expectations and the covariance matrix were estimated, as indicated earlier, by traditional sample estimators, and the vector of portfolio weights was computed according to formula (5). For this portfolio, the history of 60 in-sample returns was compared to the 60 in-sample S\&P 500 Index returns, and the initial sigma level $k_{\text {initial }}$ was determined. Then the procedure began to run on a sliding basis, in which the window moved into the out-of-sample period, adding the first out-of-sample month and skipping the oldest in-sample month, retaining thus span of 60 observations of returns. For this new span of returns, a new sigma level $k_{\text {new }}$ was calculated and compared with the initial sigma level. If the new sigma level is not worse than the initial sigma level (i.e. if $k_{\text {new }} \geq k_{\text {initial }}$ ), then there is no need to rebalance the portfolio. However, if the new sigma level is lower than the old sigma level, it signifies that the portfolio deteriorated under the interpretation of the Six Sigma methodology. Hence, it may be possibly improved by rebalancing. This possibility is investigated further by updating the portfolio weights with respect to the new window of historical returns. To this end, estimates of the vector of expectations and of the covariance matrix were recomputed and formula (5) was employed again to determine new portfolio weights. With these new weights, the new sigma level $k_{\text {new(2) }}$ was calculated and confronted with the sigma 
level $k_{\text {new. }}$. If the new sigma level with the recomputed weights $k_{\text {new(2) }}$ is not better than the new sigma level with the initial weights $k_{\text {new }}$ (i.e. if $k_{\text {new(2) }} \leq k_{\text {new }}$ ), then it is extremely unsuitable to make any changes to the portfolio and no rebalancing is recommended. It follows from the fact that the portfolio at the new set of weights worsens in its sigma level in comparison to the initial set of weights. On the contrary, if the new sigma level with the recomputed weights $k_{\text {new(2) }}$ is better than the new sigma level with the initial weights $k_{\text {new }}$ indeed, then it is advisable to rebalance the portfolio at the new recomputed weights.

However, with initial portfolio construction and on any rebalancing, some transaction costs are induced given by the rate of transaction costs set to $\delta=0.1 \%$. Transaction costs are derived from the absolute values of individual purchases to the portfolio at its creation or from changes in absolute amounts of individual positions at its rebalancing.

In computations and preparing graphical presentations, the software $\mathrm{R}$ version 3.0.1 ( $\mathrm{R}$ Core Team, 2013) was employed with several of its libraries, quadprog (Turlach and Weingessel, 2013), timeseries (Wuertz and Chalabi, 2013), PerformanceAnalytics (Carl et al., 2013) and tseries (Trapletti et al., 2013).

The results and the behaviour of the rebalancing strategy considered under the pursuit of Markowitz minimum-variance portfolios are summarized graphically in Fig. 2 and numerically in Table 3. Fig. 2 shows how the initial investment of $\$ 100,000$ changed over time for the three samples of sigma level rebalancing (Sample 1, Sample 2 and the full sample) as well as for the fictive investment into the index. The final value of portfolios without the effect of transaction costs in both graphs is shown at the beginning of the gray vertical strip (which is the very start of 2014) and here the strategies quit. At the ending of this gray vertical strip on the right, the net final values of portfolios are displayed inclusive of transaction costs.

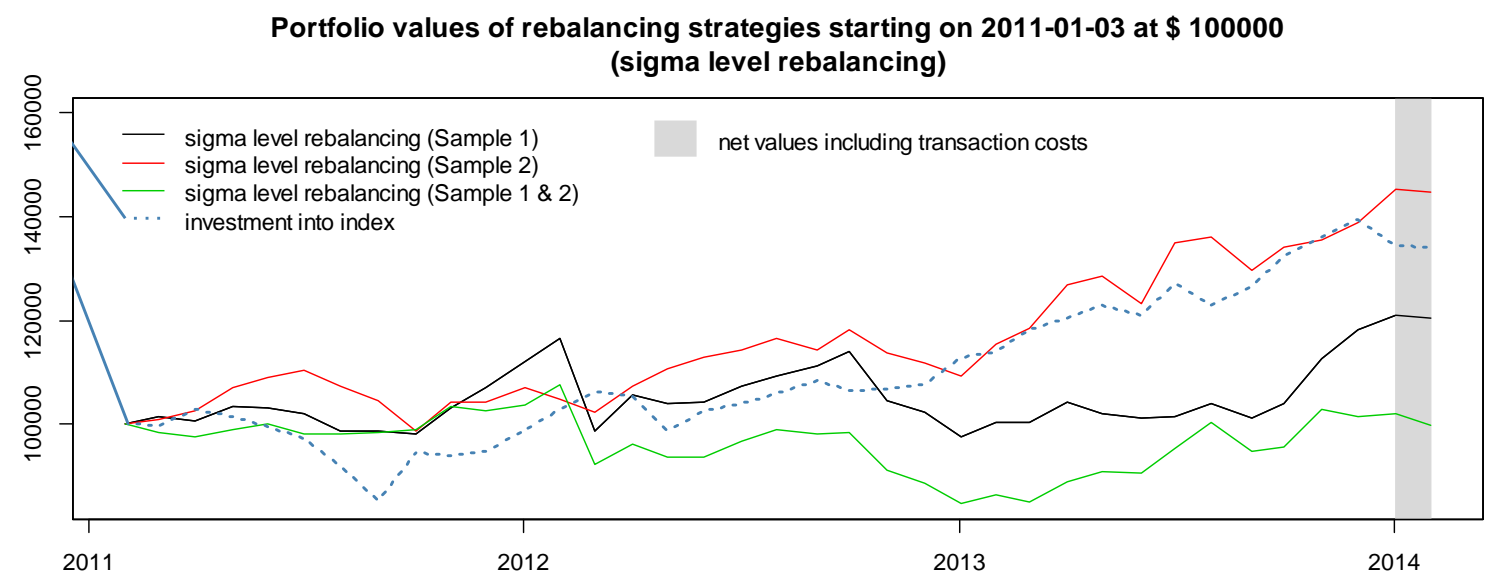

Figure 2 The price development of the strategies under consideration Source: The authors.

Table 3 contains information on the performance of the rebalancing strategies. The first three lines of information for each strategy are the final portfolio value, the total transaction costs and the net final portfolio value. The other three lines inform on the common performance (irrespective of the performance of the benchmark index) and the last three lines 


\section{APPLICATIONS OF \\ Mathematics and Statistics \\ IN ECONOMICS}

International Scientific Conference | Poland • 27-31 August 2014

shows the performance relative to the index. For the sake of completeness, excess returns are defined as exceedances of portfolio returns over benchmark returns.

Table 3. Performance descriptive statistics of the juxtaposed rebalancing strategies

\begin{tabular}{|c|c|c|c|c|}
\hline Rebalancing strategy & Sample 1 & Sample 2 & Sample 1 \& 2 & Index \\
\hline Final portfolio value (\$) & 121075 & 145258 & 101936 & 134310 \\
\hline Total transaction costs $(\$)$ & 741 & 495 & 2189 & 100 \\
\hline Net final portfolio value (\$) & 120334 & 144764 & 99747 & 134210 \\
\hline Mean return (p.m.) & $0.55 \%$ & $1.07 \%$ & $0.05 \%$ & $0.84 \%$ \\
\hline Standard deviation (p.m.) & $4.47 \%$ & $3.48 \%$ & $4.16 \%$ & $3.60 \%$ \\
\hline Mean to standard deviation ratio (p.m.) & 0.1224 & 0.3062 & 0.0132 & 0.2343 \\
\hline Mean active return (p.m.) & $-0.30 \%$ & $0.22 \%$ & $-0.79 \%$ & NA \\
\hline Active standard deviation (p.m.) & $5.76 \%$ & $5.20 \%$ & $5.60 \%$ & NA \\
\hline Information ratio (p.m.) & -0.0514 & 0.0430 & -0.1406 & NA \\
\hline
\end{tabular}

Source: The authors.

All in all, the results are not satisfactory and are surprising. The development of portfolio values as depicted in Fig. 2 suggests clearly that both Sample 1 and the full sample underperformed the S\&P 500 Index and only Sample 2 yielded a praiseworthy price development during the out-of-sample period. The Sample 2 portfolio both copied the underlying S\&P 500 Index commencing the start of 2013 and finished at a higher net value than the investment into the index did. Also the results in Table 3 confirm the superiority of this portfolio in terms of performance as it exhibits not only a high mean to standard deviation ratio but it also shows a positive information ratio as the only portfolio constructed under the proposed rebalancing strategy. It is worthy of remark that the full sample should better copy the underlying S\&P 500 Index than Sample 1 and Sample 2 only, but its performance is not acceptable for the investor.

\section{Conclusion}

The attention of the paper is devoted to utilization of the Six Sigma methodology in a definition of rebalancing strategies that are of vital importance to investors who create their portfolios at financial markets. However, after a portfolio is created, it is questionable whether this portfolio should or should not be rebalanced and its composition reconsidered over the investment period and this dilemma is exacerbated by the fact that each rebalancing incurs some transaction costs. In addition, each rebalancing strategy requires some criteria when one should intervene. In the paper, this criterion is derived from the Six Sigma concept of sigma level under the interpretation of portfolios as investment processes with some quality characteristic. In this, the criterion of rebalancing intervention is simply that one should rebalance only when the sigma level of the held portfolio deteriorates. Although the idea proposed and formulated in the paper is pioneering, the authors admit that this idea needs some refinement and see some room how to do it, but still hope that this paper will incite a fruitful discussion in academic circles.

Use of this rebalancing strategy is explained in an empirical example whose design sincerely speaking - suffers from some imperfections, yet it indicates that even this rebalancing strategy need not be universally best. One should pay more care to asset preselection in portfolio creation and these assets should not be selected at random but with respect to their market capitalization across individual industries of an economy. What is even more sensitive is the choice of the portfolio selection method. In this regard, one may remark that minimum-variance portfolio selection may not be an optimal method (but serves well the 
demonstrative purpose in this paper) and that tracking method of portfolio construction should be entertained in this cause.

It is the firm determination of the authors to continue in this research and to elaborate further refinements of the method.

\section{Acknowledgements}

The paper was prepared under the ægis of the grant scheme VEGA No. 1/0765/12 Research into possibilities and perspectives of employing traditional and alternative approaches in financial management and financial decision-making in the changing economic environment.

\section{References}

1. BAÑUELAS, R., ANTONY, J., BRACE, M. 2005. 2001. An application of Six Sigma to reduce waste. In Quality and Reliability Engineering International, 2005, vol. 21, iss. 6, pp. 553-570.

2. BREYFOGLE, F. W. 2003. Implementing Six Sigma: smarter solutions using statistical methods. 2nd ed. Hoboken, NJ : Wiley. 2003. ISBN 978-0471265726.

3. CARL, P. et al. 2013. PerformanceAnalytics: econometric tools for performance and risk analysis. R package, version 1.1.0, http://cran.r-project.org/web/packages/Performance Analytics/ index.html.

4. KWAK, Y. H., ANBARI, F. T. 2006. Benefits, obstacles, and future of six sigma approach. In Technovation, 2006, vol. 26, iss. 5-6, pp. 708-715.

5. LINDERMAN, K. et al. 2003. Six Sigma: a goal-theoretic perspective. In Journal of Operations Management, 2003, vol. 21, iss. 2, pp. 193-203.

6. MONTGOMERY, D.C. 2001. Introduction to statistical quality control. 4th ed. New York : Wiley. 2001. ISBN 0471316482.

7. PRIGENT, J. L. 2007. Portfolio optimization and performance analysis. Boca Raton, FL : Chapman \& Hall/CRC, 2007. ISBN 1-58488-578-5.

8. R CORE TEAM 2013: R: a language and environment for statistical computing. Vienna: R Foundation for Statistical Computing, 2012, http://www.r-project.org/.

9. SCHROEDER, R. G., LINDERMAN, K., LIEDTKE, CH., CHOO, A. S. 2008. Six Sigma: definition and underlying theory. In Journal of Operations Management, 2008, vol. 26 , iss. 4 , pp. 536-554.

10. STAMATIS, D. H. 2004. Six Sigma fundamentals: A complete introduction to the system, methods, and tools. New York : Productivity Press. 2004. ISBN 1-56327-292-X.

11. TRAPLETTI, A., HORNIK, K., LEBARON, B. 2013. tseries: Time series analysis and computational finance. $\mathrm{R}$ package, version 3010.97, http://cran.r-project.org/web/ packages/tseries/index.html.

12. TURLACH, B. A., WEINGESSEL, A. 2013. quadprog: functions to solve quadratic programming problems. R package, version 1.5-5, http://cran.r-project.org/package=quadprog.

13. WUERTZ, D., CHALABI, Y. 2013. timeSeries: Rmetrics - financial time series objects. R package, version 3010.97, http://cran.r-project.org/web/packages/timeSeries/index.html.

14. ZU, X., FREDENDALL, L. D., DOUGLAS, T. J. 2008. The evolving theory of quality management: The role of Six Sigma. In Journal of Operations Management, 2008, vol. 26, iss. 5, pp. 630-650. 